\title{
THE USE OF PITUITRIN IN INOPERABLE CANCER.
}

\author{
By J. H. NORGATE, Bristol.
}

In the wards of a large Poor-law Hospital are always to be found many cases of malignant disease in their later stages. These patients have been seen at other hospitals, possibly been operated upon without success, and eventually drift to their last resting-place labelled as 'inoperable and incurable'.

There are four cardinal points present in these cases: ( $a$ ) Hopeless melancholy; (b) Profound cachexia; (c) Liability to hæmorrhage; (d) Offensive discharges. In the Southmead Infirmary, Bristol, during the past year exactly 100 cases of malignant disease have been recognized; and although it may not always be kind to prolong the lives of such poor sufferers, yet if anything can be done to combat these four points and to give some sort of comfort to the patients in their last days, it is our duty to do it. By letting them drift into the next world with the kindly aid of morphia, we miss the opportunity of studying the disease, and the cure and cause of cancer will never be made plain. The post-mortem findings of a case of cancer are not so interesting as the gradual watching of the progress of the case which, by the by, is not often seen by the student in the general hospitals of the present day, owing to the hiatus, shall I call it, between the operating theatre and the mortuary.

During a severe outbreak of enteric fever in 1919, finding that pituitrin (posterior infundibular) controlled the hæmorrhage cases without any bad symptoms, I tried it on a case of sudden and severe hamorrhage from an extensive epithelioma of the tongue with enlarged cervical glands, by injecting 1 c.c. into the tongue muscle.

Case 1.-Epithelioma of tongue.

H. M., male. The patient was blanched and apparently choking from hæmorrhage. On injection of pituitrin all bleeding stopped at once, and there was no repetition of it throughout his case ; the glands decreased in size ; and in a week he could take solid food. I gave him weekly injections into his tongue for three months, and he made rapid improvement, put on flesh, and the cachexia disappeared. He continued nine months in this state; then a hard mass formed in his liver, the growth in the tongue remaining the same, the glands slightly enlarged, and he died very emaciated. The first injection was given on May 12, 1919, and he died on April 27, 1920. His melancholy and suicidal tendencies improved up to about a month before his death.

C'ase 2.-Malignant growth of lower jaw.

.J. J. R., male. A railway porter, admitted to the Southmead Infirmary, March 16, 1920. He had been pronounced 'inoperable' at both hospitals in Bristol ; sections were taken of the growth. There was a history of illness for eighteen months; a large growth was present underneath the tongue, hiding it from view, starting on the left side of the lower jaw, and forming a huge fungating growth in the neck and indurated 'truffle'-like excrescences in the chin. There had been frequent and very severe hæmorrhages from the mouth, and another occurred in the ambulance on the way to the hospital. He had been fed through the corner of his mouth by a jubber tube fixed on to a feeder. He was very anæmic and emaciated, and there was cxtreme fotor, so much so that the other patients made a complaint about it. Two days later I was summoned from a distance to see him, as he was then bleeding furiously from his mouth. I injected 1 c.c. pituitrin into the centre of the growth, and hamorrhage ceused at once. During twenty-one months he had from one to two injections every week, either into the growth itself or into the chin, but later, when the tumour became too sessile the injection was apt to be wasted, and there was little result. He had only two hæmorrhages, the first when I inadvertently put the needle into the inferior dental artery, the second in the week before he died; in both cases they were at once relieved by an injection. Fig. 472 depicts the growth before and after a typical injection of 1 c.c. The patient gained weight, and was able to eat solid food up to a month before he died. The discharge was not at all objectionable, and was of a milky purulent character. His tongue became clearly visible and movable, and the whole growth had gradually shrunk in size, 


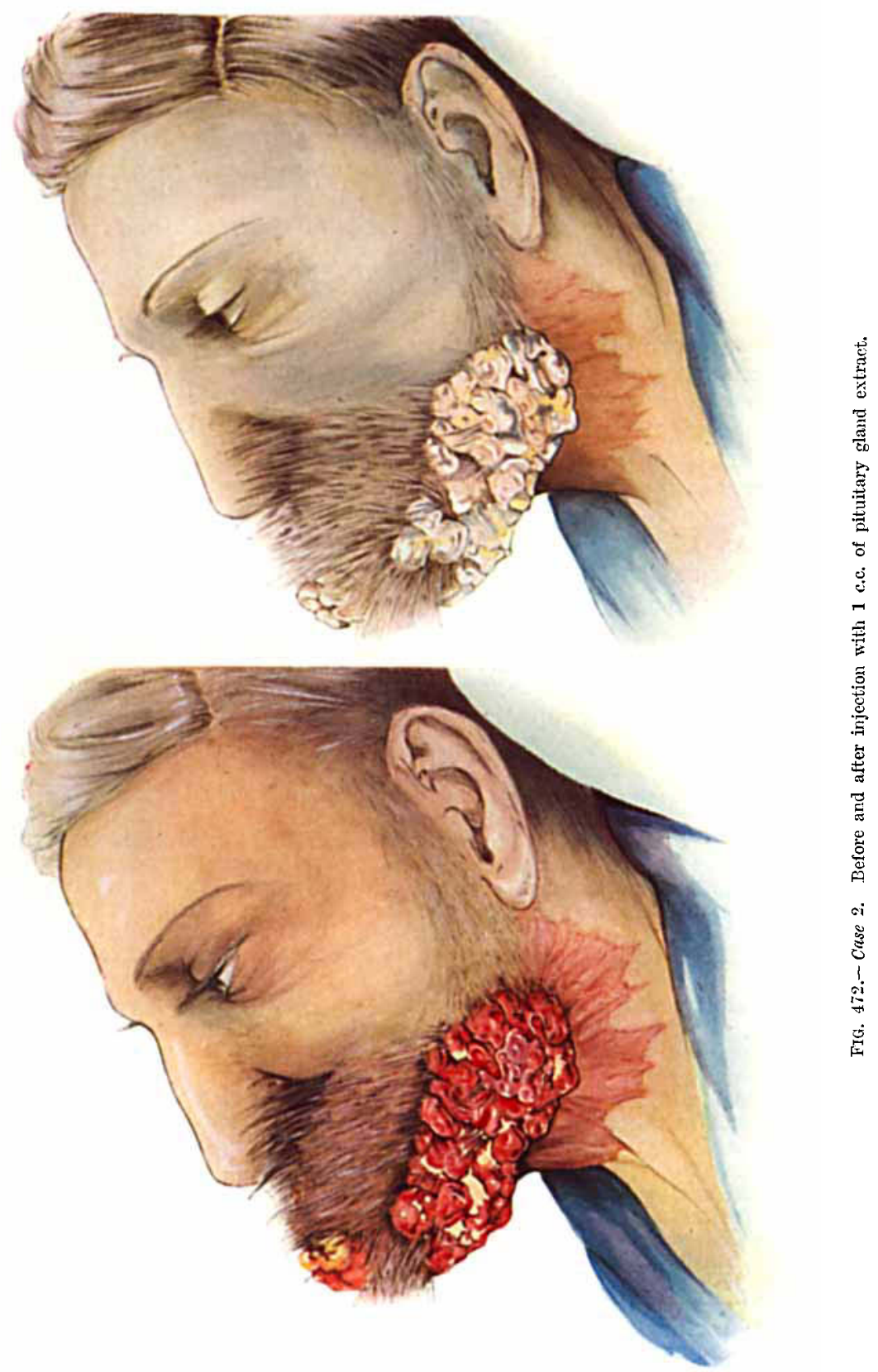




\section{PITUITRIN IN INOPERABLE CANCER}

leaving a well-marked scar in places where the skin had healed. He had been up, and about the grounds for quite twelve months, and enjoyed life, being very bright, cheerful, and hopeful.

Within a few seconds after the injection-occurring more rapidly in the later ones he has always become intensely anæmic, with acute pain down his spinc-" as if the spine was being crumpled up" ; in a few minutes he was himself again.

The effect on the growth was of great interest, as it could readily be seen on the large surface on his cheek. The colour gradually faded until it was almost paper-white. The whole growth appeared to shrivel, it exuded a milky-white fuid, and remained contracted for about twenty minutes. The growth did not bleed when the circulation was restored. It was interesting to watch the healing process, and to see small fibrous bands forming in the growth and dividing it up into sprouting spaces. As it gradually healed on the left side of the face, it approached the mid-line of the neck.

Two injections a week gave no better reaction than one. The patient appeared to look upon them in the light of a tonic. He developed no more enlarged glands, and no secondary growths elsewhere. During his last month he had great dysphagia and dyspnos, and the growth had appeared again under his tongue. He died Nov. 12, 1921 .

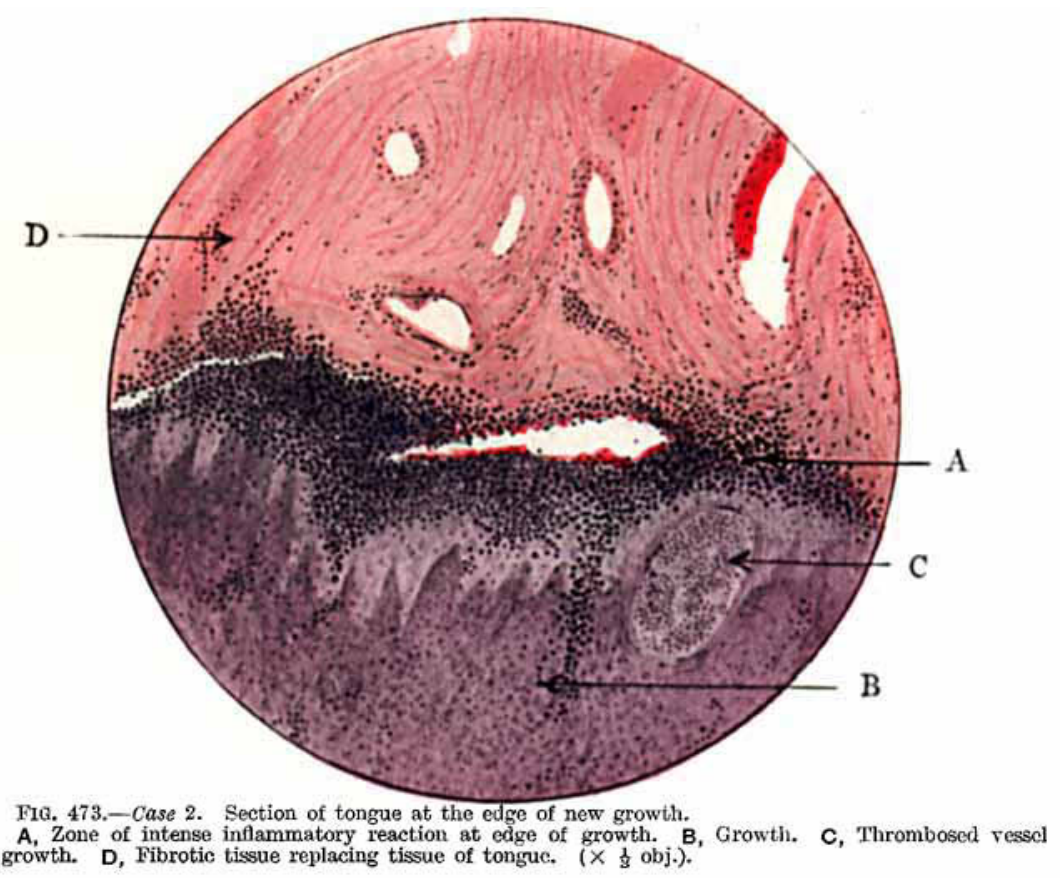

The post mortem showed no secondary growths in other organs, but the original tumour had extended downwards towards the pharynx and air-passages. The external growth had shrunk from the level of the external meatus to a point 13 in. from the lobule of the ear. There was also cirrhosis of the liver (alcoholic), and a cyst of the left kidney. 'The heart and lungs were quite normal.

Pathological Report by Dr. Hadfield, Pathologist to the Bristol General Hospital.

Three pieces of tissue were received for section: (1) Portion of original lumour; (2) Sessile portion of original tumour; (3) Skin previously affected by nerv growth.

Sections of 1 show a projecting mass of completely keratinized squamous epithelium, lying on a thick base of tumour tissue, whose general structure and arrangement is typical of a rather slowly-growing squamous-celled carcinoma, except that practically all the vessels supplying the glowth are thrombosed, and their lumina filled by many polymorphonuclear leucocytes. In consequence, in several purts of the growth there are obvious degenerative changes, the most common consisting of focal collections of degenerate tumour cells, containing nuclear fragments, and surrounded by a cell exudate of mononuclear cells and polymorphonuclear leucocytes. The tumour tissue between these foci shows no marked changes (Fig. 473).

Sections of 2 show the same essential changes as (1), but cell-nest formation is more perfect, This part of the tumour was originally of slow growth. 'The keratinized centres of many of the 
cell nests are infiltrated by phagocytes, and the growth generally shows much more widespread degeneration.

Sections of 3.-The pathological changes in the sections of the skin previously affected by the new growth are confined to the subcutaneous tissue. The skin is intact, there is no epithelial down-growth; there is a diffuse subcutaneous inflammatory reaction superimposed on a very obvious general fibrosis. This reaction is perivascular in distribution, and a cell exudate surrounds most of the vessels, a few of which are thrombosed. There is no evidence in the section of malignant disease. There are many sebaceous glands which appear normal.

Conclusions.- (1) Both sections of the tumour are typical of squamous-celled carcinoma, with areas of degeneration, due to the thrombosis of the vessels supplying the growth; (2) The degeneration is focal, the tumour tissue between is active; (3) The changes are not typical of infection, but closely resemble those produced by $x$ rays.

Out of the 100 cases in the hospital I have injected 36 , with varying results ; 3 have been successfully operated upon by the surgeon. The seat of injection varies; preferably it should be into the growth itself, especially in the mouth. For bladder, vaginal, and rectal cases it is made into the perineal tissues or the buttocks.

The immediate effects vary. In twenty seconds the patient feels a severe pain either in the back or abdomen, and a sensation of squeezing of the growth. Then follows the intense anxmia, which may be frightening at times, with weakening of the pulse; a little brandy will relieve this at once, but it is better to let the patient feel the full and prolonged effect if possible, as the constriction of the vessels is greater. Some cases have reported a sensation of impending death, and a gradual return to life, but there has been no loss of consciousness.

I have used Ferris and Co. and Parke Davis preparations, and the patient will soon gauge the strength of the preparation by its effects upon him. I find the anæmic cases after severe hæmorrhages present some difficulty ; the pituitrin helps them, and if discontinued there is a liability to sudden collapse. The pain has been relieved in many cases ; but when the ulceration extends and deep nerves are affected, morphia becomes a necessity - the pituitrin loses its effect. I withhold morphia as long as possible.

I have given 5 c.c. in enteric hæmorrhage in twenty-four hours without ill effect, but have not gone beyond 3 c.c. per week in cancer cases. There has been no death within a week of an injection. It should be given in bed, and a rest of one hour in bed afterwards is advisable. There has been no nausea or vomiting after the injections. An improvement in appetite and gain of weight have been seen in almost every case, and the patients' impression that something is being done for them has dissipated their melancholy; it is not very cheering to be told that nothing more can be done for one.

I have noticed an effect of pituitrin in delaying the onset of secondary glands and growths, also the tendency it has to break down and liquefy the hardened masses, and to render the growths abortive, and I would advise its use after primary operation on a growth to prevent a recurrence in the nearest glands. Secondary deposits in other parts of the body are conspicuous by their absence after pituitrin.

There appears to be a point beyond which it is not advisable to go-the patient can hold no more in his system-especially in aortic disease. I am sure that pituitrin is the most powerful drug we have in use for prevention and stoppage of hæmorrhage in cancer cases : its action is certain, very prompt, and very lasting. The effect on the discharges is various : in some cases it is very deodorant if given into the growth itself, in others not so.

No claim can be made that pituitrin is a cure for cancer, for it only delays the growth by cutting off its blood-supply for a limited time; but as a general tonic to the system, as a great antagonist to cachexia and its attendant distress of mind and body, and as an agent in producing a remission for a time of the 'last sentence' which we know must irrevocably be carried out, its value is great. This prolongation of life for a year or more in patients who might have been expected to live about a month, has been of great interest, and has given me encouragement to hope that further experiments may lead to the unlocking of the hitherto closed door that leads to the cure of cancer.

My thanks are due to Dr. Hadfield for his examination and report of the specimen submitted to him, and to Miss Pillers for her drawings. 


\section{PITUITRIN IN INOPERABLE CANCER}

\section{FURTHER REPORTS OF CASES.}

Case 3.-Fpithelioma of hand.

J. T., male, age 79. Always refused amputation. Had injections for 5 months. First injection, May, 1919. Improvement at first; tumour now growing more vigorously ; patient losing weight; no secondary growths in other organs; a few glands in axilla; no hamorrhage. Injection into wrist.

Case 4.-Carcinoma of cervix.

C. R., female, age 83. Cancer affecting vaginal walls; severe hæmorrhage and fœtor. Three injections. First injection, June, 1919. Keeping fairly well; no hæmorrhage ; rather offensive discharge; losing weight slowly; no cachexia now. Injection into vaginal wall and perineum.

Case 5.-Carcinoma of rectum.

J. I., male, age 70. Severe hamorrhage and foctor. Three injections into perineum. First injection, Sept. 24, 1920. Cachexia gone; up and about all day; huge mass still to be felt in rectum, hollowed out; no hæmorrhage, and little discharge.

Case 6.-Large growth in right antrum.

H. J., female, age 75. Growth appears through nose and roof of mouth, growing from a tooth. Tumour known to have existed for 3 months before admission. First injection, Oct. 20, 1920. Marked effect and anamia. Growth halted for 9 months; now growing very slowly; no cachexia ; slight hæmorrhage once.

Case 7.-Carcinoma of labium majus.

R. B., female, age 70. Inoperable on admission, growing then 6 months. First injection, Dec. 1, 1920. Six injections ; refused more; still alive; has had no hæmorrhage ; fotor now more marked; gradually tunnelling out the pelvis ; general health fair, but anæmic; has morphia at night.

Case 8.-Carcinoma of rectum.

H. P., male, age 62. Offensive discharge and slight hæmorrhage ; very anæmic on admission. Had four injections into perineum. First injection, Oct. 20, 1920. Cachexia now gone; no hæmorrhage ; tunnelling of growth now going on ; was melancholic, but is now bright.

Case 9.-Malignant disease of breast.

C. T., female, age $7_{2}$. No ulceration; secondary glands neck and chest. First injection, Oct., 1920. No progress of tumour; glands much the same; no cachexia ; seems in fairly good health.

Case 10.-Carcinoma of cervix.

S. D., female, age 43 . Severe hæmorrhages and foctid discharges; losing weight rapidly. First injection, Sept., 1921. Comes up fortnightly for injections into perineum ; is looking better ; has had no more hæmorrhages, and discharge is less offensive; much brighter.

Case 11.-Epithelioma of tongue.

S. A., male, age 59. Severe hæmorrhages, always controlled by pituitrin into growth ; marked fotor with emaciation. No real improvement except control of hanorrhage. Died in five months.

Case 12.-Carcinoma of breast.

A. B., female, age 56 . Growth 3 months. Secondary glands in axilla. Very obese woman. Also cardiac dilatation and asthma. Admitted Oct. 4. First injection, Oct. 10, 1920. After two injections the whole solid mass of breast broke down and discharged, leaving a shell of skin and muscle ; no hæmorrhage after, but fotor very disagreeable. Had four injections. Very delirious and noisy ; morphia. Died in Jan., 1921, in a heart attack.

Case 13.-Carcinoma of breast.

E. D., female, age 72 . Growth 9 months. There is a deep, depressed circular pit over left breast, with hardened edges, exposing the ribs with deep infiltration of the chest. Severe hamorrhages, controlled with pituitrin into the edges of the crater; marked foetor and cachexia. First injection, Nov. 1, 1920. Improved, and took her food well; glands in axilla disappeared after two injections. Relapsed, and died $\Lambda_{\text {pril }} 26,1921$.

Case 14.-Carcinoma uteri.

M. D., female, age $7 \%$. Severe hæmorrhages for 6 months. Admitted, Nov. 13. First injection, Nov. 20, 1920. Hamorrhages controlled by pituitrin, no more occurring; secondary growth in liver; improved a little. Died April 30, 1921.

Case 15.-Cancer of tonsils and structures near.

A. D., male, age 58. Admitted Dec. 7, 1920. Many enlarged glands in neck gave him much pain and extreme anxmia ; great dysphagia and dyspncea. Marked melancholia. First injection, Dec. 10, 1920. Improved at first; no hæmorrhage at all. Died May 27, 1921. 


\section{THE BRITISH JOURNAL OF SURGERY}

Case 16.-Cancer of uterus.

A. J., female, age 32. Known to exist 1 month. Pelvic glands. Severe hæmorrhages and cachexia. First injection, Nov. 5, 1920. Marked effect; no hæmorrhage. Died Jan. 6, 1921.

Case 17.-Carcinoma of cheek and antrum.

R. M., male, age 85. 'Three months' hamorrhage and extreme foetor. First injection, Oct. 12, 1920. Breaking down of mass and glands, and clearing out of whole of right side of mouth; intense foctor ; no hamorrhage. Died Jan. 1, 1921.

Case 18.-Carcinoma of rectum.

M. Q., female, age 56. Hæmorrhage and eachexia marked. First injection, Oct. 20, 1920. Had several injections weekly. Cachexia markedly improved; no hæmorrhage; fœetor bad towards the end. Died June 10, 1921.

Case 19.- Epithelioma of tongue.

W. S., male, age 72. Locked mouth and huge growth in neck on right side. First injection, Oct. 23, 1920. Two injections liquefied the growth in the neck, and it discharged externally. Unable to be fed by the mouth, which was in a terrible condition. Died of septic pneumonia Nov. 4, 1920.

Case 20.-Carcinoma of breast.

D. S., female, age 69. Glands in axilla. Also aortic valvular disease. First injection, Dec. 30, 1920. Had little, if any, effect. Died Feb. 16, 1921.

Case 21.-Carcinoma of breast.

R. T., female, age 75. Secondary deposits in hip after removal of breast; spontaneous fracture. First injection, Dec. 20, 1920. Little, if any, improvement. Early morphia. Melancholia supervened. Died April 30, 1921.

Case 22.-Carcinoma of neck.

T. Y., male, age 48. Huge glands ; marked cyanosis ; mental symptoms ; loeked mouth. Two injections. No improvement beyond softening of glands, which relieved pressure on his vessels. Removed to insane wards, and died soon after.

Case 23.- Dpithelioma of larynx.

R. B., male, age 83. Tracheotomy. First injection, May 4, 1921. Improved up to a point ; appetite better, and much more cheerful; growth spread to the œesophagus; no hæmorrhage. Died Oct. 22, 1921. Growth 8 months.

Case 24.- Cancer of uterus.

E. C., female, age 76 . Severe hæmorrhage and cachexia. One injection given March 20, 1921, that controlled the hæmorrhage. Made no progress. Died May 9, 1921. Growth 6 months.

Case 25.-Cancer of left breast.

A. C., female, age 57. Similar to Case 13. Deep pit with raised edges. Admitted July 29, 1921. Severe hæmorrhages at every dressing; marked anæmia and cachexia. First injection, Sept. 6, 1921. Glands in axilla disappeared after few injections. Now getting worse, and walls breaking down. Growth 9 months.

Case 26.-Fithelioma of lower lip and jaw.

W. D., male, age 74. Fungating mass with glands. Extreme anæmia and cachexia from repeated hæmorrhages. First injection, June 20, 1921. No further hæmorrhage, and some improvement. Died in lavatory, Aug. 12, 1921. Growth 9 months.

Case 27.--Cancer uteri.

C. ${ }^{7}$ L., female, age 56. Very advanced ; frequent hæmorrhages. First injection, Jan. 5, 1921. No further hæmorrhage, and discharge less foetid. Died May 4, 1921. Growth 6 months.

Case 28.-Cancer of neck glands and tongue.

S. L., male, age 55. Husband of Case 27. Fungating mass. First injection, May 1, 1921. Softening of glands; no hæmorrhage. Died May 26. Growth 6 months.

Case 29.-Sarcoma of lower $\mathbf{j}$ aw.

A. D., male, age 48. Enlarged glands; no ulceration. Growing 3 months. First injection, June 30, 1921. Three injections produced intense anæmia of growth. Patient went out against medical advice. Growth softening. Mentally strange.

Case 30.-Epithelioma of antrum.

W. F. N., male, age 47. Two operations. Fungating mass. Admitted April 30, 1921. Several injections, which relieved pain and size of growth; no hæmorrhage. Morphia. Died Aug. 11, 1921. 
Case 31.-Cancer of rectum.

W. O., male, age 7o. Marked. Nearly moribund on admission. History of repeated hamorrhages. Anæmia and cachexia very marked. First injection, Feb. 1, 1921. Improved very much at first; cachexia disappeared; able to be up and about. Pain returned, and morphia was given. Died Aug. 1, 1921.

Case 32.-Epithelioma of tonsil.

E. P., female, age 41. Spreading to tongue. Many glands. First injection, April $20,1921$. Improved at first; glands softened and discharged; less dysphagia; no hxmorrhage. Glands appeared on other side; jaundice. Morphia. Died June 18, 1921.

Case 33.-Fpithelioma of palate and tongue.

S. S., male, age 78. Repeated hæmorrhages, rapidly controlled by pituitrin in mouth, not so quickly when given in arm. Marked anxmia, cachexia, and melancholia. First injection, Aug. 1, 1921. Improved and took solid food. Relapsed, and died Nov. 2, 1921.

Case 34.-Carcinoma of rectum.

R. W., female, age 79. Growth 9 months. Repeated hxmorrhages. Admitted Jan. 13, 1921. One injection stopped hæmorrhage. Secondary growth in liver. Died June 22, 1921.

Case 35. - Epithelioma of antrum.

A. W., female, age 77 . Huge fungating mass growing through nose and mouth. Sick 18 months; intensely anamic, and cachexia marked. First injection, April 22, 1921. Improved very much. Had several injections. Died suddenly Aug. 1, 1921.

Case 36.-Carcinoma uteri.

E. C., female, age 54. Intense ancmia. Sick 9 months; cachexia and melancholia. Admitted Aug. 31. Had three injections. Improved; no more hemorrhage. Died Nov. 12, 1921.

Case 37.-Cancer of tonsil and palate.

'T. C., male, age 72. Admitted Oct. 23, 1920. Had several injections. Glands softened, returned on other side; no hæmorrhages after injections. Died June 20, 1921. 